Notes

1. S. Touval, Somali Nationalism: International Politics and the Drive for Unity in the Horn of Africa (Cambridge: Harvard University Press, 1963): 52.

2. R. Beachey, The Warrior Mullah (London: Bellew Publishing, 1990): 41, 159.

3. Colonial Office, "Report of the Somaliland Protectorate Constitutional Conference Held in London in May 1960" (London: Her Majesty's Stationery Office, 1960): 2.

4. Touval, Somali Nationalism.

5. Ibid., 78.

6. I.M. Lewis, A Modern Nistory of Somalia: Nation and State in the Horn of Africa (Boulder: Westview Press, 1988): 144.

7. R. Gorman, Political Conflict on the Horn of Africa (New York: Praeger, 1981): 133.

8. Colonial Office, Report of the Somaliland Protectorate Constitutional Conference, 2.

9. Touval, Somali Nationalism, 103.

10. Ibid., 112

11. S. Mohamed, "Les Politiques du Developpementen Somalie:Les Facteurs Socio-Economiques." Doctoral dissertation, Ecole des Hautes Etudes en Sciences Sociales, Paris, 1983, 27.

12. Touval, Somali Nationalism, 113.

13. L. Pestalozza, The Somalian Revolution (Paris: Societe d'edition Afrique Asie, Amerique Latin, 1974): 207.

14. Gorman, Political Conflict, 211.

15. Ibid.

16. M. Hassan, "Status of Human Rights in Somalia," Horm of Africa 3, no. 2.

17. P. Henze, The Horn of Africa: From War to Peace (London: McMillan Academic and Professional Ltd., 1991): 155.

18. Africa Watch, "Somalia: A Government at War With Its Own People," (Africa Watch, 1990): 76.

19. S. Mohamed, "Siyad's Vendetta Against the North," New Africa no. 240 (September 1987): 21.

20. I.M. Lewis, "The Ogaden and the Fragility of Somali Segmentary Nationalism," Horn of Africa 13, no. 1 and 2 (1990).

21. Africa Watch, "Somalia: A Government at War With Its Own People," 3.

22. Africa Watch, "Somalia: No Mercy in Mogdisho, the Human Cost of the Conflict and the Struggle for Relief," (Africa Watch, March 1992): 4.

23. P. Biles, "Going It Alone," Africa Report (January-February 1992): 59-60.

\title{
Political Decay in Somalia: From Personal Rule to Warlordism
}

\author{
Daniel Compagnon
}

The Somali people's high expectations after Siad Barre's oppressive regime was overthrown in January 1991 have since turned into bitter disillusionment and mass suffering. According to some UN reports, 4.5 million people in Somalia are facing a food shortage and 1.5 million will starve in the coming months. In May and June 5,000 children under the age of five died daily ${ }^{1}$ and 7,000 people died in Baydhaabo in June. The case of the interriverine region exemplifies how the famine is a direct outcome of political internal strife and lawlessness: the farmers interviewed in the Bardeera area explained that the Mareehaan militias of Siad Barre looted their herds, water pumps and sowing seeds several times, while those of Baydhaabo said they were looted by United Somali Congress (USC) gunmen as well. ${ }^{2}$ This human disaster is probably the largest one in Somali history and beyond anything that could have been foreseen even two years ago when Siad Barre was still in power.

Those who bear the main responsibility are the Somalis of the various factions who cultivate warfare and mafia-type behaviour. The lack of concern shown by foreign powers, despite their involvement in Somali politics during the last thirty years, accounts for the international community's low-scale initiatives, especially in contrast with the attention focused on other parts of the world (Yugoslavia or Cambodia). But it is also quite clear that the lack of far-sighted leadership and political planning on the so-called "liberation fronts" are crucial factors in the Somali crisis. In addition, historical as well as sociological factors, some of them deeply rooted in the Somali social fabric, have to be taken into consideration.

Daniel Compagnon teaches at the Centre du recherches et d'études pour Afrique orientale, Paris, France.
The rapacity of the political entrepreneurs and their impatient drive to secure state power at any cost, added to the preexisting factors of political decay and clan-based factionalism, are all part and parcel of Siad Barre's legacy.

\section{The Bitter Legacy of Personal Rule}

The analytical notion of personal rule is designed to capture a contemporary style of governance well represented in Africa $^{3}$ that combines authoritarian rule, a low level of institutionalization of political processes (including decision making), concentration of power in the hands of the ruler, and private appropriation of state resources through corruption, patronage and prebends. 4 Siad Barre's regime evolved from an original pattern of bureaucraticauthoritarian rule in the early 1970 s towards personal rule in the 1980 s and eventually into its corrupt variety called "sultanism" (i.e., when the ruler makes no attempt to restrain from the abuse of force). ${ }^{5}$ This type of governance had major negative effects in Somalia and provide the background of the current crisis.

\section{Economic Ruin Through Patrimonialism}

This patrimonial dimension ${ }^{6}$ developed under Siad Barre's regime to an extent unknown in the 1960s, and the Ogaden war might have been a turning point in this respect. ${ }^{7}$ Embezzlement of public funds, corruption of ministers and civil servants in connection with public markets and development projects, ${ }^{8}$ baksheeshes at all levels of the bureaucracy, illegal trafficking by relatives or friends of the president-all these were tightly linked to a direct access to state power. These were the spoils of personal rule. Patron-client ties were built between those who had that access 
and others, especially Hawiye businessmen. With the absolute power to appoint, transfer, sack or even jail, Siad Barre was the ultimate boss of the whole network. His personal patronage was eagerly sought for and he got his share in the biggest deals. Somalis used to say that Siad Barre looked at the national state and economy as "parts of his teashop." This patrimonial behaviour enlarged the group of people who had a personal interest in the continuation of his devastating rule. ${ }^{9}$

It alsoimplied that investmentcapital was predominantly oriented towards speculative trading activities and all kinds of illegal trafficking detrimental to the productive side of the economy. ${ }^{10} \mathrm{~A}$ stratum of wealthy and corrupt businessmen (many of whom were penniless in the early 1970s) arose from all the clans. As the economic crisis deepened and the power circle narrowed down to the ruler's family, and while the unleashed repressive bodies (the National Security
Barre's downfall. Interestingly, some of those who benefited financially from the previous regime were in the best position to make money from the looting.

\section{State Disintegration}

Despite prominent officers in the state hierarchy since 1969, from the top down to the remote rural districts, the apparent backbone of the military regime was never able to act against the will of Siad Barre, let alone depose him. From the beginning, he viewed the officers either as his personal clients or as his personal foes. ${ }^{11}$

The army, whose support was a crucial political resource for imposing an authoritarian state in the 1970 s, was perceived as a threat after the abortive coup of 1978. Through purges, accelerated promotions of Mareehaan and (to a lesser extent) related Darood clan officers, while the military from other clan families were transferred to

\section{By the time the opposition fronts were able to take over, there was no state as such to seize, and they were not prepared to provide an alternative to prevent anarchy.}

Service, Hangash, some army units and Red Berets) raised the level of violence and extortion to such levels that they provoked a massive displacement of population in the North and the eventual uprisingin the South, theleading officials of the regime completely plundered the state budget and the banking system. In this respect, the looters who have been ravaging the capital city since January 1991 are the heirs of Siad Barre and his clique for three reasons:

- The first to loot were Siad Barre's Red Berets and other military units at the bottom of the hierarchy and his patrimonial servants at the top.

- The country was bankrupt and food shortages had already begun during the summer of 1990 . For impoverished urban dwellers and destitute nomads, looting became the only means of survival.

- There was no moral restraint (the Somali crisis is also spiritual) as robbery became a way of life even before Siad administrative positions, Siad managed to keep the potential hostile elements of the armed forces at bay. He never allowed the minister of defence to build a personal power position. ${ }^{12}$ The patrimonial nature of his policy was exemplified by interferences from members of his family in military appointments. Colonels and generals were part of the president's patronage network; they had to remain loyal to him and his close relatives, whether they had a command or were temporarily in the Cabinet. ${ }^{13}$ Inclusion in the regular army of the Ogaadeen, Warsangeli and Dulbahante militias to fight against the Isaaqs in the North and the creation of units exclusively drawn from the Mareehaans eventually discredited the very idea of a national army.

The military apparatus offers a good example of Somali institutional decay as a result of the state's patrimonialism. Other examples of institutional decay include the diplomatic service since Abderahmaan Jaama Barre became minister of foreign affairs, cooperatives under Warsame Indolleh, finances and banking, etc. The state disintegration began long before the overthrow of the ruler. Since 1987 there has only been a semblance of a state: not a single public service was working effectively, the administration was paralysed by factional struggle at its head for the longawaited succession and also by insurgency at the periphery.

Hence, the random killings and systematic abuses of the Isaaqs in the North as well as the Ogaadeens in the Jubba area or the Hawiyes in the central regions, ${ }^{14}$ were signs that Siad Barre's regime had reached the stage of sultanism, a variant of personal rule characterized by arbitrary violence. By the time the opposition fronts were able to take over, there was no state as such to seize, and they were not prepared to provide an alternative to prevent anarchy.

From the summer of 1988 onwards, there was a combination of political repression against targeted clans and private use of violence by predatory units and individuals of the former "national" armed forces-already in the process of disintegration-who used their power to rape, kill and loot freely. The classic distinction between private illegitimate violence and public coercion disappeared. Many former military men later joined the clan militias or the armed gangs.

\section{Vendetta Politics and the Exacerbation of Clan Rivalries}

Another striking feature of Siad Barre's survival tactics in the 1980s, as many scholars have already noted, was his extensive use of clanism ${ }^{15}$ as a political resource. To secure lasting loyalties, he filled the key positions in the army, police, diplomacy and security force with members of three Darood clans closely related to his own reer: Mareehaans, Dulbahantes and Ogaadeens, ${ }^{16}$ yet the importance of this alliance should not be exaggerated. Contacts with elders and the support of 
some prominent men in the clan do not necessarily mean that the whole clan is behind the regime: other members exiled abroad could be engaging in some opposition activities at the same time. ${ }^{17}$ Siad Barre played on the segmentary social organization: while he was courting a subclan or a lineage that received prebends and honours, another branch of the same clan was given a hard time. On the other hand, many Isaaqs and Hawiyes served the regime until the late 1980 s and were instrumental in the ruler's claim that he was still able, unlike the armed opposition, to rally significant support among the clans, a crucial point for his public image.

Clanism also provided a means to weaken the opposition, which was accused of being tribal-minded. The Somali Salvation Democratic Front (SSDF) was labelled a Reer Mahamud organization in order to reduce its appeal, so that the regime would gain the support of smaller lineages of the Majeerteen clan. Siad Barre also played on the Hawiyes' resentment of the Majeerteens for their alleged domination of the Somali polity in the 1960s. Similarly, the Somali National Movement (SNM) was presented as an Isaaq chauvinist and secessionist group by Siad Barre's propaganda, skilfully using some elements of truth to damage the image of the whole movement. The ruler tried several times to stir up the rivalries between the main Isaaq clans, ${ }^{18}$ in order to diminish the support for the SNMin the North. Furthermore, the state was involved in interclan feuds among the nomad pastoralists. By giving money and weapons tothe clan segments whose goodwill he wanted to win, thereby weakening lineages hostile to his rule, Siad Barre repoliticized lineage competition, deliberately breaking with the postcolonial state's long-term efforts to appear neutral. In the late 1980 s to the early 1990s some of these conflicts were deliberately instigated or encouraged to prevent discontented clans ${ }^{19}$ from forming a coalition. By doing so, the personal ruler sharpened clan rivalries and brought back clan-based factionalism as a major factor in Somali politics. The actions of Siad Barre and his aides in creating the Somali crisis should not be forgotten too quickly. Nonetheless, his contenders and successors did not fare better.

\section{The Deadly Gamble of Political Entrepreneurs in the Post-Siad Barre Era}

According to press reports, Somalia is confronted with a tribal war, which suggests atavistic hatreds and endless conflicts. It is an inaccurate description of a segmentary society whose clan families are not differentiated along cultural and linguistic lines, and in which the disintegrative effects of personal rule. Although the SSDF (in 1981) and the SNM (between 1984 and 1987) got closer tothis objective, theirleaders either made mistakes that ruined the whole plan or showed that they were just paying lip service while calling for unity of the opposition. The United Somali Congress (USC) is no exception, since it was intended to voice the interests of the Hawiyes. Siad Barre's propaganda deliberately fuelled these clan rivalries, but the fact that these divisions persisted after his downfall shows that his machiavellian abilities were not the main factor: there are still very few Somalis

\section{None of these organizations, which claimed they were fighting against a dictatorship and for a democracy, had a clear vision of what should be done to establish such a regime and rebuild the country.}

competition between the segments is constantly reshaped by shifting alliances. ${ }^{20}$ It also falls short of explaining the various dimensions of the factional competition for supremacy. If Somalia's current upheaval was a traditional feud between neighbouring clans, it should have been possible to end it through the traditional heer and shir. ${ }^{21}$

\section{Shortcomings of the Former Opposition to Siad Barre's Regime $^{22}$}

From the early 1980s the Somali opposition was divided into rival organizations that were politically weak mainly for the following reasons. They recruited massively from a single clan or clan family, thereby limiting their appeal to other groups that were automatically suspicious of alleged clan hegemony. The clan factor was always at the core of Somali politics and played an important role in the factional struggle of the 1950s and 1960 s, even within the nationalist parties. But in the atmosphere of growing fear and distrust in Siad Barre's Somalia, no single clan could achieve a violent overthrow of the regime because they had limited constituencies at the fronts. The regime actually collapsed due to the who have a political vision that extends beyond asserting their own clan rights and strength. Another consequence of this kind of recruitment was the formation of military units along the lines of social segmentation at the level of the primary lineages. This later facilitated the lineage-based factionalism within the fronts.

There was no coordination of activities, especially military cooperation, between the armed fronts. Hence, the Majeerteen resented the lack of support when they were under attack in the Mudugh area between 1979 and 1982, and the Isaaqs bitterly pointed out the lack of southern solidarity while they werebeing harassed andlater massacred by the regime's squads. "Let the noses of the Isaaqs be bloodied" was later countered by the vengeful "Let Muqdisho be destroyed as Hargeisa was." ${ }^{23}$ We can see today how counterproductive these attitudes were. Significantly, the exception here is the agreement signed in August 1990 between the SomaliNationalMovement, United Somali Congress/Aydiid and Somali Patriotic Movement/Ahmed 'Umar Jess. The purpose of this alliance was mainly to preempt and share state power in the event of the fall of the 
regime, especially in defiance of the other groups, the Manifesto, Somali Salvation Democratic Front and USC/'Ali Wardiigley.

None of these organizations, which claimed they were fighting against a dictatorship and for a democracy, had a clear vision of what should be done to establish such a regime and rebuild the country. The paucity of their political programs was probably intended to diminish their leaders' responsibilities during the transition period, but it also denoted a lack of careful analysis of the Somali crisis. The simplistic slogans branding the "bloodthirsty dictator" and the "bankrupt regime" were indeed useful for mobilizing support, but fell short of providing a model for governance. ${ }^{24}$

Since the overthrow of Siad Barre, the clan-based politico-military organizations appeared exclusively motivated by the struggle for supremacy and the sharing of the spoils. The war that devastated Muqdisho from November 1991 to March 1992, killed as many as 14,000 and injured twice this number, according to Africa Watch, cannot be explained otherwise. But even in the North, where the SNM enjoyed several months of peace and unchallenged political hegemony, nothing decisive was achieved. This can be explained by the lack of resources, the lack of coherent plans to rebuild the country, and, above all, by the factional competition within the SNM, which reached a peak during the serious fighting in Burao and Berbera.

\section{Rival Entrepreneurs, Merchants and Clan-Based Factionalism}

In May-June 1991 the Manifesto group was an attempt to prevent civil war and clan fighting after the collapse of Siad Barre's regime, but the group disbanded at the time it was most needed. Also, from the beginning some of its leaders had their own agenda and the race for power began as soon as Siad Barre left the capital city. A national reconciliation government failed to appear because the USC, which officially controlled Muqdisho, was not able to prevent the massacres of Darood civilians and other non-Hawiyes. This can account for the rise of a pan-Darood alliance in early spring 1991, which came very close to conquering Muqdisho before it was stopped by USC troops. Clan rivalries rapidly evolved into open warfare when the state was perceived as an easy prey.

The war between the clans seemed to revive the traditional competition between lineages for scarce resources, which was one of the fundamental characteristics of the precolonial pastoral society. However, differences between the current instability and the traditional pattern lie not only in the prizes (state split of USC dates back to the very beginning of the organization in January 1989 when a group of mainly Abgaal people in exile in the Western countries elected 'Ali Osooble Wardiigley as chairman. The Sa'ads then decided to stay in the SNM that Wardiigley had just left and General Aydiid, long courted by the SNM leadership, joined them in Ethiopia. Then a USC unitwas organized there in the spring of 1990 and from then on there were two Hawiye guerrilla movements fighting the regime. Judging from the propaganda warwaged outside the country between USC/Aydiid and USC/Rome, and from the fierce

\section{The war between the clans seemed to revive the traditional competition between lineages for scarce resources, which was one of the fundamental characteristics of the precolonial pastoral society.}

resources including foreign aid, instead of pastures and wells) or the weapons (bazookas and artillery, instead of spears), but also in the role played by political entrepreneurs and merchants.

The case of the self-proclaimed Republic of Somaliland illustrates the clan elders' ability to defuse the tensions at the local level between neighbouring lineages, especially during the first six to eight months of 1991. However, it also demonstrates their powerlessness in preventing factional fighting at the national state level. They are not able to impose their will on the incumbent leaders who are already largely discredited.

Political entrepreneurs, whetherwith a military or a civilian background, rely on clan solidarity and clan chauvinism as political tools to achieve their goals. They use their own clan as much as they serve it (very much like Siad Barre did with the Mareehaans until he went into exile). Although the conflict between Sa'ads and Abgaals is reminiscent of some politicking in the 1950s when 'Abdullaahi' Iise was prime minister, it is still difficult to understand unless one considers the personal rivalry between Mahamed Farah Aydiid and 'Ali Mahdi Mahamed in their bid for power. The comments made in private on both sides, one could tell that this factional rift would not be easily mended. Both factions are based on lineage alliances that formed during the fighting-currently Haber Gidir/Hawaadle versus Abgal/ Murursaade - but are cemented more effectively by personal loyalties and individual rewards. This may explain why a Salebaan general serves in 'Ali Mahdi's forces and a Murursaade businessman and former politician supports Aydiid. Although the clans provideyoung men for the struggle, their elders do not control the whole process. The political entrepreneurs are constantly trying to broaden the alliance on which they rely in order to strengthen their autonomy. It is precisely what Aydiid has been doing since he defeated Siad Barre in late April this year.

The merchants also play a key role in the current upheaval, since they finance the war as well as the physical survival of the political entrepreneurs and their cliques. At the same time, they take advantage of the scarcity of food or the demand for khat and the large number of destitute and hungry looters to make huge profits. ${ }^{25}$ Now that increased international aid is being delivered, they dictate their prices for transportation as 
well as for military protection. Their interest is so closely linked with the state of anarchy that they might be more willing to support warlords than invest in peace and reconstruction. Without their money to supply ammunition, buy back the loot and selectively feed the gunmen, the factions would have been unable to sustain themselves during eighteen months of unrest.

\section{Militarization of the Political Conflict: Warlordism in the Making}

The prolonged political squabble among various political parties and military fronts did not bring about any lasting government coalition capable of reconstructing the state. The competition between political entrepreneurs within each of the main groups, especially the uncompromising stands of the two factions fighting for Hawiye supremacy, has jeopardized the implementation of the Djibouti agreement of July 1991, the most notable effort at national reconciliation. The subsequent months of warfare and atrocities deepened the rift of distrust between the clans and strengthened the position of military strongmen (most of them former army officers) in each camp.

Since there is no credible political settlement in sight and because there is a high level of insecurity in all the de facto autonomous regions, time seems to favour the warlords who will try to build their own mini-states in the areas they control. As the inevitable partners of the NGOs and international relief agencies, the warlords can extract more resources to reinforce their authority. Ironically, more humanitarian intervention might help them consolidate their power. They might be able to deliver the goods in terms of stability and minimum order, but they can scarcely be regarded as champions of democracy. Even the North might evolve along the same lines if the SNMleadership remainsinefficient and immobile and fails to reach a consensus.

The threat of war will remain since none of the warlords will voluntarily renounce his claim to state power. When they make compromises, it is only for tactical expediency. This political culture is consistent with Somali traditional values and with oral poetry that praises dominance by force asserted in the battlefield and looting of those who are defeated. ${ }^{26}$ For many years, Somali politicians and the majority of scholars emphasized the "democratic" nature of the pastoral society and neglected this other side of its culture. Sayyid Mahamed 'Abdulle Hasaan, who was able to build an autocratic system of rule by using the resources of lineage politics and religious charisma, definitely remains a model for the modern warlords.

The picture is extremely gloomy and I tend to believe that the only way out of the nightmare is to call for a full intervention of the United Nations, not only to establish peace in the country, preserve its unity and save the people from famine, but also to preempt the power and create a new democratic order to preserve equal rights for all the lineages and, if necessary, to quell the open resistance of the warlords-in other words, establishing a new trusteeship for Somalia. :

\section{Notes}

1. See The Montreal Gazette, June 17, 1992.

2. See The New York Times, July 19, 1992, AFP, July 27, 1992.

3. See R.H. Jackson and C.G. Rosberg, Personal Rule in Black Africa: Prince, Autocrat, Prophet, Tyrant. Berkeley: University of California Press, 1982; Max Weber, Economy and Society: An Outline of Interpretive Sociology, 2 vols. Edited by Guenther Roth and Claus Wittich. Berkeley: University of California Press, 1968; Guenther Roth, "Personal Rulership, Patrimonialism, and EmpireBuilding in the New States," World Politics XX, no. 2 (January 1968): 194-206.

4. See the notion of prebend, as applied to a postcolonial African state, in Joseph Richard, Democracy and Prebendal Politics in Nigeria: The Rise and Fall of the Second Republic (Cambridge: Cambridge University Press, 1987): 55-68.

5. See Daniel Campagnon, "Political Crisis in Somalia: The Legacy of An Exhausted Personal Rule." Paper presented at the
1990 meeting of the African Studies Association, Baltimore, Maryland. On the bureaucratic-authoritarian system, see Charles Andrain, Political Change in the Third World (New York: Unwin Hyman, 1988) 22-30.

6. See the theorical debate summarized and updated in Jean-Francois Medard, "L'Etat néo-patrimonial en Afrique Noire," in Etats d'Afrique Noire, Formations, Mécanismes et Crise, edited by J.F. Medard (Paris: Karthala, 1991): 32354 . See also the notion of "belly politics" in J.F. Bayart, $L$ 'Etat en Afrique La Politique du Ventre (Paris: Fayard, 1989): 281-315.

7. See A.K. Galaydh, "Notes on the State of the Somali State," Horn of Africa XIII, nos. 1 and 2, 1-28.

8. The figure of 40 percent of each contract was put forward in David D. Laitin and Said S. Samatar, Somalia: Nation in Search of $A$ State (Boulder: Westview Press, 1987): 95 .

9. The petty corruption developed in the late 1980 s as a result of the economic crisis. It seemed that Siad Barre more or less legitimized these practices with the notion of "hawlfududayn" (a "tip" to help civil servants perform their duties). Petty corruption is crucial for securing the compliance of large sections of the population, according to interviews.

10. See Norman Miller, "The Other Somalia: Illicit Trade and the Hidden Economy," American Universities Field Staff Reports: Northeast Africa Series 29 and 30 (1981).

11. Those who failed to comply were among the victims of the political repression since 1969. See Amnesty International, Somalia: A Long Term Human Rights Crisis (London: Amnesty International, September 1988) 36.

12. Salad Gaveire was arrested in 1971, Mahamed'AliSamatarwas firedin April 1981 and again in January 1987, while "promoted" to prime minister. "Umar Haaji Mahamed, his successor in 1981, was jailed in June 1982, and the too confident Aadan 'Abdulle "Gabyow" received the same treatment in July 1989. The president always kept direct control of the armed forces - at least until his car accident-and never appointed another commander-in-chief.

13. In the late 1980s the number of senior army staff in the senior ranks far exceeded the number of available commanding officer positions in the active service. For example, in December 1986 twenty-two colonels were 
promoted to generals at the same time! See Africa Confidential 28, no. 7 (May 1, 1987). This is an example of patrimonialism: many of these officers were Mareehaans or MOD.

14. Africa Watch, Somalia: $A$ Government At War with Its Own People: Testimonies About the Killings and the Conflict in the North (London: The Africa Watch Committee, January 1990). See also other publications of Africa Watch concerning the southern regions.

15. "Clanism," as opposed to "tribalism," better describes the segmentary nature of Somali society. See I.M. Lewis, A Pastoral Democracy: A Study of Pastoralism and Politics Among the Northern Somali of the Horn of Africa (London: Oxford University Press, 1961). On clanism under Siad Barre, see Laitin and Samatar, Somalia: Nation in Search of A State, 155-63, and I.M. Lewis, $A$ Modern History of Somalia: Nation and State in the Horm of Africa (Boulder: Westview Press, 1988): 220-22, 250 and Campagnon, "Political Crisis in Somalia."

16. In the mid-1980s the artillery and tank units surrounding the capital were under Mareehaan command, as were one-third of brigade commandants. In total, $\mathbf{5 0}$ percent of the police and army commandants in the regions and districts and 80 percent of the military sectors and army divisions were Darood. See "Somalia: Military Politics," Africa Confidential 27, no. 22 (October 26, 1986): 1-2; Lewis, A Modern History of Somalia, 256. For diplomacy, see the letter of Ibrahim $\mathrm{H}$. Addow, published in Horn of Africa 5, no. 1 (1982): 75, and Mahamoud Hassan, "Status of Human Rights in Somalia," Horn of Africa 3, no. 2 (1980): 6.

17. The Garad 'Ali Garad, of the Dulbahante/Farah Garad primary lineage, lived in exile in London formany years and his heir' Abdulqani negotiated an agreement with the Isaag/ Habar Ja'lo that undermined the ruler's policies. The whole clan did not consider Sulayaman Daffle as its natural leader. The second Dulbahante member of the SRC withdrew in 1983 and several Dhubahante officials like 'Ali Khalif Galaydh defected in the 1980s, according to interviews. For examples of Mareehaans who suffered from Siad Barre's personal rule, see A. Sultan's letter in New African (June 1987).

18. He wanted to gain the support of the Habar Awal. This clan made up the majority of Hargeysa's population and is well represented in the Isaaq business class, as well as among the waadad. Many Habar Awal did not accept the loss of the SNM leadership in 1983 and became critical of Ahmed Silanyo's conduct of the organization. Siad Barre tried to appease the elders of the clan by appointing Ina-Lah-was vice-president and later vice-prime minister. The latest tricks in this game were the sudden appointment of Mahamed Hawaadle Madar as prime minister on September 1, 1990 and of 'Umar Arteh Galib in early January 1991, according to interviews.

19. See the analysis of some of these feuds in Gérard Prunier, "Stuctures de clan et pouvoir politique en Somalie," Cultures et Développement 17, no. 4 (March 1987): 602-97. See also "Somalia on the Brink of Civil War," Horn of Africa 6, no. 3 (1983): 41; Laitin and Samatar, Somalia: Nation in Search of a State, 161-162; and Said S. Samatar, "An Open Letter to Somali Scholars: Should Siad Host the Next SSIA Congress? Some Second Thoughts," Horn of Africa 13, nos. 1 and 2 (1990): 88-95.

20. See I.M. Lewis, A Pastoral Democracy, the major study on the pastoral Somalis.

21. The heer is the jural contract that requires lineages to form military alliances or diya-payinggroups; the shir is the council of elders that makes decisions on collective issues, including war, at all levels of society. On this, see Lewis, $A$ Pastoral Democracy.

22. See Daniel Campagnon, "The Somali Opposition Fronts: Some Comments and Questions," Horn of Africa XIII, nos. 1 and 2 (January-June 1990): 29-54; Gérard Prunier, "A Candid View of the Somali National Movement," Horn of Africa XIII and XIV, nos. 1, 2, 3 and 4, 107-20.

23. SeeSamatar, "An Open Letter toSomalist Scholars" for the first quotation. The second comes from interviews.

24. The original program of the SSDF was more sophisticated with its Marxist phraseology-thanks to the SWP and SDLF intellectuals-but did not provide concrete plans for recovery.

25. See Roland Marchal, "La guerre à Mogadiscio," Politique Africaine 46 (June 1992): $120-25$.

26. See Said S. Samatar, Somalia: A Nation in Turmoil (London: The Minority Rights Group, August 1991): 33.
FELLOWSHIPS AVAILABLE

York University

THE JACQUELINE

GREATBATCH MEMORIAL FELLOWSHIP AND

\section{ATLE GRAHL-MADSEN MEMORIAL FELLOWSHIP}

ACan. $\$ 10,000$ Jacqueline Greatbatch Memorial Fellowship and a Can. $\$ 10,000$ Atle Grahl-Madsen Memorial Fellowship have been established by the Centre for Refugee Studies and the Graduate Program in Law, York University, Toronto, Canada, to permit two individuals to pursue studies leading to Master of Laws or Doctor of Jurisprudence at the Osgoode Hall Law School.

The fellowships will be awarded annually to the candidates with excellent academic records in law, and who want to pursue graduate research in international refugee law or a closely related field. Preference will be given to applicants with a demonstrated commitment to human rights advocacy or service to the disfranchised and to the advancement of human dignity through public international law.

In addition to conducting graduate research, the Greatbatch and GrahlMadsen fellows will contribute throughout the academic year to the work of the Refugee Law Research Unit of the Centre for Refugee Studies.

Candidates should submit a curriculum vitae (resumé), academic records and two reference letters to either the LL.M. or D. Jur. program, together with a statement of intent no later than January 31, 1993 to:

The Director

Graduate Program in Law

Osgoode Hall Law School, York University

4700 Keele Street, North York, ON

Canada M3J 1P3 